\title{
An Evaluation of Industrial Promotional Agencies in Himachal Pradesh
}

\author{
Dr. Usha Sharma * \\ Associatet.Professor, Deptt. Of Commerce, Centre for Evening Studies H. P.UNI. Shimla
}

\begin{abstract}
Industrialisation is a comparatively recent phenomenon in Himachal Pradesh. It gained momentum during the last two decades. Monetary and fiscal benefits as incentives and subsidies to industry, provided by the state as well as the central government, and the availability of quality infrastructure with basic amenities, have played a key role in the industrial development of the state. Industries in Himachal Pradesh, are now producing from traditional to a wide spectrum of high -tech products like computer monitors, magnetic components, high quality precision components, tele-communication equipments, electronics, drugs and pharmaceutical Is, processed food, textiles, and spinning products. The contribution of the industrial and manufacturing sector has increased significantly. In this backdrop, present paper, is an attempt to analyse the availability of infrastructural facilities apart from knowing the reason(s) for setting up industrial units in Himachal Pradesh. The paper is divided into two sections: section I deals with perception of the Industrial Promotional Agencies in the development of industries in Himachal Pradesh and section II deals with critical evaluation of the role of Industrial Promotional Agencies in promoting industrial industrialisation in Himachal Pradesh with the help of factor analysis.

The Government has launched various policies and programmes for the promotion and development of industrial activities in the state. In order to execute these policies and programmes, various agencies such as: Directorate of Industries, District Industry Center, Small Industries Service Institute, Small Industries Development Bank Of India, State Finance Corporation etc. has been established. An attempt has been made in this paper to know the perceptions of respondents regarding the role of industrial promotional agencies in promoting industries in the state.
\end{abstract}

\section{Objective of the Study:}

The main objective of the present paper is to critically evaluate the role of Industrial Promotional Agencies in development of industries in Himachal Pradesh.

\section{Research Methodology:}

In the present work, a sample of 131 industrial units has been selected from different industrial areas of the study state. In order to make the sample representative, proper weightage has been assigned to the units according to their size and product. Primary data is analysed with the help of factor analysis (Principal Component Analysis) with varimax rotation. Extraction criterion used is eigen value, should be greater than one.

\section{Registration}

Registration of industries with the DIC is necessary to enjoy the various incentives and concessions. The registration procedure in DIC has not been difficult for the new units as the State Government has notified a State Level Single Window Clearance and Monitoring Authority (SLSWC \& MA) for providing umbrella support to the existing and new ventures and for ensuring expeditious clearances from the respective departments. The opinion of respondents regarding assistance provided by industrial promotional agencies for preparation of project report and registration of industrial units reveals that majority of respondents are satisfied with the assistance provided to them by these agencies. The mean score of overall responses is 2.41 with positive skewness of .566 and standard deviation of 1.36. More than half $(55.7 \%)$ of the respondents are either satisfied or fully satisfied with the assistance provided by these agencies. Value of chi-square is also found to be highly significant at 1 and 5 percent level of significance. Thus, the analysis reveals that the entrepreneurs are largely satisfied with the assistance received from these agencies for registration of their units.

\section{Acquiring Land}

The perceptions of respondents about the role of industrial promotional agencies in acquiring land reveals that more than two-third (67.1 percent) of the respondents either agree or strongly agree with the statement. These agencies have satisfactorily assisted the industries in acquiring land is evident from the mean score of 2.35 having value of skewness of .782 and standard deviation of 1.31. Chi-square is highly significant 
at 1 and 5 percent levels of significance. Statistical analysis reveals that the opinion of respondents is concentrated towards the lower side of overall mean score. So, it is clear that industrial promotional agencies are satisfactorily assisting the industries in acquiring land.

\section{Setting up Unit}

The opinions of the respondents about the assistance provided by industrial promotional agencies in setting up the units is evenly distributed among satisfied and dissatisfied responses. Further, 29 percent of the respondents are found indifferent towards the statement. Mean score of 2.91 with negative skewness (-0.11) and standard deviation of (1.27) supports the fact that the responses are concentrated towards dissatisfactory scale. Chi-square is highly significant at 1 and 5 percent levels of significance. Thus, the role of industrial promotional agencies has not been found satisfactory in facilitation of the setting up of industrial units.

\section{Paperwork}

So far as the knowledge of various rules and regulations and assistance in its compliance is concerned, industrialists have to depend upon private professionals. The view of respondents regarding assistance from industrial promotional agencies in complying with rules and regulations reveals that three out of five respondents $(62.6 \%)$ are either satisfied or very satisfied with the assistance received from industrial promotional agencies in dealing with paper work. The mean score of aggregate responses is 2.36 skewness of (.711) and standard deviation of (1.54). Value of chi-square has also been found to be highly significant. Statistical analysis indicates that the of opinion of the respondents is skewed towards lower side of the mean, which shows that majority of the respondents are satisfied.

\section{Elucidate Information}

The Central and State Government announces various incentives from time to time for motivating the potential industrialists. Analysis reveals that four out of five respondents $(80.9 \%)$ are quite satisfied with the information provided to them regarding the incentives and concessions by the industrial promotional agencies. The overall mean score of the responses is 1.87 which indicates that majority of the respondents are either satisfied or very satisfied with the industrial promotional agencies. The value of skewness (1.40) and standard deviation (1.320) is high and positive which shows that majority of the respondents are fully satisfied with the statement that industrial promotional agencies provide knowledge of various incentives available. Chi-square is also highly significant at 1 and 5 percent levels of significance.

\section{No Objection Certificate from State Pollution Control Board}

More than half $(55.8 \%)$ of the respondents are dissatisfied or strongly dissatisfied with the statement that they obtained no objection certificate (NOC) from the State Pollution Control Board without any hassle. Government departments are still suffering from a disease of red tapeism. Bureaucracy seems to be the life blood of all the Government

Table 1: Perception of the Respondents Regarding Role of Industrial Promotional Agencies

\begin{tabular}{|c|c|c|c|c|c|c|c|c|c|c|c|}
\hline Particulars & $\begin{array}{c}\text { Strong-by } \\
\text { Agree }\end{array}$ & Agree & $\begin{array}{l}\text { Neither } \\
\text { Agree Nor } \\
\text { Dis-agree }\end{array}$ & $\begin{array}{c}\text { Dis- } \\
\text { agree }\end{array}$ & $\begin{array}{l}\text { Strong-ly } \\
\text { Dis-agree }\end{array}$ & Mean & $\begin{array}{c}\text { Std. } \\
\text { Deviati } \\
\text { on }\end{array}$ & $\begin{array}{c}\text { Skew- } \\
\text { ness }\end{array}$ & Kurtosis & $\begin{array}{c}\text { Chi- } \\
\text { Square }\end{array}$ & $\begin{array}{l}\text { Asymp. } \\
\text { Sig. }\end{array}$ \\
\hline $\begin{array}{ll}\text { Assist } & \text { in } \\
\text { Registration } & \end{array}$ & $\begin{array}{c}47 \\
(35.9 \%)\end{array}$ & $\begin{array}{c}26 \\
(19.8 \%\end{array}$ & $\begin{array}{c}30 \\
(22.9 \%)\end{array}$ & $\begin{array}{c}13 \\
(9.9 \%)\end{array}$ & $\begin{array}{c}15 \\
(11.5 \%)\end{array}$ & 2.4122 & 1.36365 & .566 & -.865 & 28.504 & .000 \\
\hline $\begin{array}{l}\text { Assistance in } \\
\text { Acquiring Land }\end{array}$ & $\begin{array}{c}40 \\
(30.5 \%)\end{array}$ & $\begin{array}{c}48 \\
(36.6 \%)\end{array}$ & $\begin{array}{l}13 \\
(9.9 \%)\end{array}$ & $\begin{array}{c}16 \\
(12.2 \%)\end{array}$ & $\begin{array}{c}14 \\
(10.7 \%)\end{array}$ & 2.3588 & 1.31891 & .782 & -.577 & 41.710 & .000 \\
\hline $\begin{array}{l}\text { Facilitation in } \\
\text { Setting up the Unit }\end{array}$ & $\begin{array}{c}26 \\
(19.8 \%)\end{array}$ & $\begin{array}{c}20 \\
(15.3 \%)\end{array}$ & $\begin{array}{c}38 \\
(29.0 \%)\end{array}$ & $\begin{array}{c}33 \\
(25.2 \%)\end{array}$ & $\begin{array}{c}14 \\
(10.7 \%)\end{array}$ & 2.9160 & 1.27725 & -.111 & -1.030 & 14.229 & .007 \\
\hline $\begin{array}{l}\text { Assist Paper in } \\
\text { Work Formalities }\end{array}$ & $\begin{array}{c}58 \\
(44.3 \%)\end{array}$ & $\begin{array}{c}24 \\
(18.3 \%)\end{array}$ & $\begin{array}{c}16 \\
(12.2 \%)\end{array}$ & $\begin{array}{c}9 \\
(6.9 \%)\end{array}$ & $\begin{array}{c}24 \\
(18.3 \%)\end{array}$ & 2.3664 & 1.54026 & .711 & -1.033 & 54.229 & .000 \\
\hline $\begin{array}{l}\text { Provide } \\
\text { Knowledge About } \\
\text { Various Incentives }\end{array}$ & $\begin{array}{c}77 \\
(58.8 \%)\end{array}$ & $\begin{array}{c}29 \\
(22.1 \%)\end{array}$ & $\begin{array}{c}1 \\
(0.8 \%)\end{array}$ & $\begin{array}{c}13 \\
(9.9 \%)\end{array}$ & $\begin{array}{c}11 \\
(8.4 \%)\end{array}$ & 1.8702 & 1.32082 & 1.402 & .552 & 138.504 & .000 \\
\hline $\begin{array}{l}\text { NOC From State } \\
\text { Pollution Control } \\
\text { Board }\end{array}$ & $\begin{array}{c}13 \\
(9.9 \%)\end{array}$ & $\begin{array}{c}29 \\
(22.1 \%\end{array}$ & $\begin{array}{c}16 \\
(12.2 \%)\end{array}$ & $\begin{array}{c}28 \\
(21.4 \%)\end{array}$ & $\begin{array}{c}45 \\
(34.4 \%)\end{array}$ & 3.4809 & 1.41068 & -.370 & -1.292 & 24.534 & .000 \\
\hline $\begin{array}{l}\text { NOC's from Other } \\
\text { Government } \\
\text { Departments. }\end{array}$ & $\begin{array}{c}6 \\
(4.6 \%)\end{array}$ & $\stackrel{9}{(6.9 \%)}$ & $\begin{array}{c}27 \\
(20.6 \%)\end{array}$ & $\begin{array}{c}37 \\
(28.2 \%)\end{array}$ & $\begin{array}{c}52 \\
(39.7 \%)\end{array}$ & 3.9160 & 1.13706 & -.885 & .042 & 56,748 & .000 \\
\hline $\begin{array}{l}\text { Arrangement of } \\
\text { Losn }\end{array}$ & $\begin{array}{c}12 \\
(9.2 \%)\end{array}$ & $\begin{array}{l}9 \\
(6.9 \%)\end{array}$ & $\begin{array}{c}15 \\
(11.5 \%)\end{array}$ & $\begin{array}{c}50 \\
(38.2 \%)\end{array}$ & $\begin{array}{c}45 \\
(34.4 \%)\end{array}$ & 3.8168 & 1.23912 & -1.049 & .170 & 58.885 & .000 \\
\hline $\begin{array}{l}\text { Acquiring } \\
\text { Working Capital }\end{array}$ & $(5.3 \%)$ & $\begin{array}{c}16 \\
(12.2 \%)\end{array}$ & $\begin{array}{c}21 \\
(16.0 \%)\end{array}$ & $\begin{array}{c}25 \\
(19.1 \%)\end{array}$ & $\begin{array}{c}62 \\
(47.3 \%)\end{array}$ & 3.9084 & 1.26765 & -.838 & -.527 & 68.046 & .000 \\
\hline $\begin{array}{l}\text { Provide Valuable } \\
\text { Information }\end{array}$ & $\begin{array}{c}28 \\
(21.4 \%)\end{array}$ & $\begin{array}{c}15 \\
(11.5 \%)\end{array}$ & $\begin{array}{c}20 \\
(15.3 \%)\end{array}$ & $\begin{array}{c}11 \\
(8.4 \%)\end{array}$ & $\begin{array}{c}57 \\
(43.5 \%)\end{array}$ & 3.4122 & 1.62609 & -.375 & -1.490 & 51.405 & .000 \\
\hline $\begin{array}{l}\text { Provide Necessary } \\
\text { Market } \\
\text { Information }\end{array}$ & $\begin{array}{c}23 \\
(17.6 \%)\end{array}$ & $\begin{array}{c}16 \\
(12.2 \%)\end{array}$ & $\begin{array}{c}25 \\
(19.1 \%)\end{array}$ & $\begin{array}{c}28 \\
(21.4 \%)\end{array}$ & $\begin{array}{c}39 \\
(29.8 \%)\end{array}$ & 3.3359 & 1.46030 & -.362 & -1.227 & 10.794 & .029 \\
\hline Recruiting Staff & $\begin{array}{c}25 \\
(19.1 \%)\end{array}$ & $\begin{array}{c}24 \\
(18.3 \%)\end{array}$ & $\begin{array}{c}30 \\
(22.9 \%)\end{array}$ & $\begin{array}{c}27 \\
(20.6 \%)\end{array}$ & $\begin{array}{c}25 \\
(19.1 \%)\end{array}$ & 3.0229 & 1.38933 & -.041 & -1.229 & .870 & .929 \\
\hline $\begin{array}{l}\text { Imparted Training } \\
\text { for Improving } \\
\text { Technical Know- } \\
\text { how }\end{array}$ & $\begin{array}{c}17 \\
(13.0 \%)\end{array}$ & $\begin{array}{c}29 \\
(22.1 \%)\end{array}$ & $\begin{array}{c}22 \\
(16.8 \%)\end{array}$ & $\begin{array}{c}27 \\
(20.6 \%)\end{array}$ & $\begin{array}{c}36 \\
(27.5 \%)\end{array}$ & 3.2748 & 1.40906 & -.183 & -1.316 & 7.893 & .096 \\
\hline $\begin{array}{l}\text { Assistance for } \\
\text { Marketing Product }\end{array}$ & $\begin{array}{c}34 \\
(26.0 \%)\end{array}$ & $\begin{array}{c}22 \\
(16.8 \%)\end{array}$ & $\begin{array}{c}35 \\
(26.7 \%)\end{array}$ & $\begin{array}{c}18 \\
(13.7 \%)\end{array}$ & $\begin{array}{c}22 \\
(16.8 \%)\end{array}$ & 2.7863 & 1.40881 & .186 & -1.185 & 9.191 & .057 \\
\hline $\begin{array}{l}\text { Harassment by } \\
\text { Government }\end{array}$ & $\begin{array}{c}29 \\
(22.1 \%)\end{array}$ & $\begin{array}{c}21 \\
(16.0 \%)\end{array}$ & $\begin{array}{c}52 \\
(39.7 \%)\end{array}$ & $\begin{array}{c}14 \\
(10.7 \%)\end{array}$ & $\begin{array}{c}15 \\
(11.5 \%)\end{array}$ & 2.7328 & 1.24545 & .182 & -.726 & 37.206 & .000 \\
\hline
\end{tabular}


An Evaluation of Industrial Promotional Agencies in Himachal Pradesh

\begin{tabular}{|c|c|c|c|c|c|c|c|c|c|c|c|}
\hline Officials & & & & & & & & & & & \\
\hline $\begin{array}{l}\text { Lack of Interest in } \\
\text { Officials }\end{array}$ & $\begin{array}{c}58 \\
(44.3 \%)\end{array}$ & $\begin{array}{c}4 \\
(3.1 \%)\end{array}$ & $\begin{array}{c}65 \\
(49.6 \%)\end{array}$ & $\begin{array}{c}2 \\
(1.5 \%)\end{array}$ & $\begin{array}{c}2 \\
(1.5 \%)\end{array}$ & 2.1298 & 1.06263 & .127 & -1.226 & 159.573 & .000 \\
\hline $\begin{array}{l}\text { Personal } \\
\text { Relations/ } \\
\text { Connections with } \\
\text { High-ups }\end{array}$ & $\begin{array}{c}81 \\
(61.8 \%)\end{array}$ & $\begin{array}{c}24 \\
(18.3 \%)\end{array}$ & $\begin{array}{c}10 \\
(7.6 \%)\end{array}$ & $\begin{array}{c}2 \\
(1.5 \%)\end{array}$ & $\begin{array}{c}14 \\
(10.7 \%)\end{array}$ & 1.8092 & 1.30156 & 1.594 & 1.287 & 152.855 & .000 \\
\hline $\begin{array}{l}\text { Unnecessary } \\
\text { Delaying Tactics }\end{array}$ & $\begin{array}{c}66 \\
(50.4 \%)\end{array}$ & $\begin{array}{c}25 \\
(19.1 \%)\end{array}$ & $\begin{array}{c}11 \\
(8.4 \%)\end{array}$ & $\begin{array}{c}12 \\
(9.2 \%)\end{array}$ & $\begin{array}{c}17 \\
(13.0 \%)\end{array}$ & 2.1527 & 1.45429 & .949 & -.586 & 80.260 & .000 \\
\hline Poor Work culture & $\begin{array}{c}16 \\
(12.2 \%)\end{array}$ & $\begin{array}{c}23 \\
(17.6 \%)\end{array}$ & $\begin{array}{c}13 \\
(9.9 \%)\end{array}$ & $\begin{array}{c}28 \\
(21.4 \%)\end{array}$ & $\begin{array}{c}51 \\
(38.9 \%)\end{array}$ & 3.5725 & 1.45724 & -.540 & -1.185 & 34.611 & .000 \\
\hline $\begin{array}{l}\text { Seriousness of the } \\
\text { officials to } \\
\text { Promote Industrial } \\
\text { Units }\end{array}$ & $\begin{array}{c}32 \\
(24.4 \%)\end{array}$ & $\begin{array}{c}30 \\
(22.9 \%)\end{array}$ & $\begin{array}{c}26 \\
(19.8 \%)\end{array}$ & $\begin{array}{c}15 \\
(11.5 \%)\end{array}$ & $\begin{array}{c}28 \\
(21.4 \%)\end{array}$ & 2.8244 & 1.47012 & .250 & -1.304 & 6.748 & .150 \\
\hline
\end{tabular}

\section{Source: Primary Probe}

Departments. The mean score of responses which is 3.48 with negative skewness (-0.370) and standard deviation of 1.410 indicates that the responses are highly skewed towards dissatisfied responses. The findings are also supported by highly significant value of chi-square. Hence, it is inferred that respondents are dissatisfied in the process of obtaining NOC from State Pollution Control Board.

\section{No Objection Certificate from other Government Departments}

Paperwork of official procedures is a burdensome part of promotional activities. Before setting up the unit no objection certificates (NOC's) from different Government departments is to be obtained. More than two third of the respondents $(67.9 \%)$ are either dissatisfied or strongly dissatisfied with this statement. High mean score of 3.91 with negative skewness of -0.885 and standard deviation of 1.137 depicts that the responses fall between dissatisfied and very dissatisfied responses on five point scale. Thus, it can be concluded that government departments need to be revolutionized so that the industrialist do not feel harassed and disappointed while going through official procedures.

\section{Arrangement of Loan}

The perceptions of respondents regarding assistance provided by industrial promotional agencies for arrangement of loans has a mean score and skewness 3.81 and -1.04 respectively which shows that majority of the respondents are dissatisfied. More than two-third of the respondents (72.6 percent) are of the view that the Industrial Promotional Agencies did not assist them in arrange of loan. Chi-square test of goodness of fit is also highly significant at 1 and 5 percent levels of significance. Thus, it can be recapitulated that assistance to industrial units in arrangement of loans by these agencies has not been up to the mark and rather have failed.

\section{Arrangement of Working Capital}

The perceptions of the respondents regarding assistance provided by the industrial promotional agencies for acquiring working capital reveals that two-third of the respondents (66.4 percent) do not agree with this view. The mean score of the responses and value of skewness are found 3.90 and -.838 respectively which signifies that the responses are highly skewed towards dissatisfied responses on five point scale. Chi-square test of goodness of fit is also highly significant at 1 and 5 percent levels of significance. Hence, it can be summed up that industrial promotional agencies have not assisted the industrial units in acquiring working capital.

\section{Dissemination of Information}

Views of the respondents regarding the information provided by Industrial Promotional Agencies for arranging factors of production shows a mixed response. More than half (51.9 percent) of the respondents either disagree or strongly disagree with this statement, whereas 32.9 percent of the respondents either agree or strongly agree. The mean score of aggregate responses is 3.41 with negative value of skewness $(-0.375)$ and standard deviation of 1.62 which indicates that majority of respondents are either dissatisfied or strongly dissatisfied with the statement. Hence, it can be concluded that Industrial Promotional Agencies are not providing requisite information to the industrialists.

\section{Market Information}

The perceptions of the respondents about the assistance provided by promotional agencies regarding market information reveals more than half (51.2 percent) of the respondents either disagree or strongly disagree, whereas only 29.8 percent of the respondents either agree or strongly agree with the statement. Most of the respondents are indifferent for the statement, as the overall mean score is 3.33 with negative value of skewness $(-0.362)$ and standard deviation of 1.460. This indicates that an overwhelming number of respondents are dissatisfied with the market related information provided by these agencies. 


\section{Assistance in Recruiting Staff}

The opinion of the respondents in relation to assistance provided by Industrial Promotional Agencies in recruiting staff depicts that two-fifth of the respondents either disagree or strongly disagree with the statement, while 37.4 percent either agree or strongly agree with the statement. Overall mean score has been found 3.02 with low negative value of skewness (-0.041) and standard deviation of 1.38 which indicates that the opinion of respondents is slightly skewed towards dissatisfied responses. Further, 22.9 percent of the respondents are found indifferent. Value of chi-square has not been found significant. Hence, it can be concluded that a large number of resp[onses are hesitant in commenting on the role played by Industrial Promotional Agencies in recruitment.

\section{Imparting Technical Know-how}

The Government has initiated various programmes and incentives to modernize and update the techniques of production in the industries. Industrial Promotional Agencies have been entrusted with the responsibility of encouraging and motivating the industrialists to modernize their methods of production. The opinion of respondents regarding role of industrial promotional agencies in imparting training for improving technical know-how reveals that nearly half of the respondents (48.1percent) are either dissatisfied or very dissatisfied with the working of these agencies as far as imparting the training is concerned. Further, 16.8 percent of the respondents are found indifferent in their views. The mean score of overall responses and value of skewness are found 3.02 and -.041 respectively. Hence, it is concluded that Industrial Promotional Agencies have not assisted industries in imparting training to the workers.

\section{Assistance in Marketing the Products}

Role of the Industrial Promotional Agencies in providing assistance for marketing the product show that 26.7 percent of the respondents are indifferent towards the statement. The mean score and value of skewness have been found 2.78 and 0.186 respectively with standard deviation of 1.409. Statistical analysis reveals that the responses to the statement are slightly skewed towards dissatisfaction level. Therefore, it is concluded that majority of the respondents feel that the Industrial Promotional Agencies have not helped in marketing their product.

\section{Harassment by Government Officials/Agencies}

The perception of respondents regarding the statement that Government agencies rather harass them is reported by two-fifth of the total respondents where equal number of respondents are indifferent. The mean score of aggregate responses is 2.73 with low positive skewness of 0.182 and standard deviation of 1.245. Statistical analysis reveals that the responses are concentrated towards disagreement on five point scale. Chisquare test of goodness of fit has been found highly significant. Hence, it can be concluded that that Government officials/agencies are harass the industrialists.

\section{Lack of Interest Shown by Officials/Agencies}

Nearly half (47.4 percent) of the respondents are of the opinion that Government officials do not show any interest in solving their problems. The mean score of 2.73, value of skewness (0.182) and standard deviation of 1.062 reveals that the responses are concentrated towards agreement scale. Value of chi-square has also been found to be highly significant. Hence, it can be concluded that Government officials/agencies are hardly concerned with the problems faced by entrepreneurs.

\section{Relations/Connections with High-Ups}

The perceptions of respondents regarding the statement that personal connections with Government Officials are very important for getting work done shows a mean score of 1.80 which indicates that the respondents either agree or strongly agree with the statement. High and positive value of skewness (1.59) and standard deviation (1.301) also indicates that the responses falls between agree and strongly agree. Four out of five respondents (80.2 percent) either agree or strongly agreement scale with the statement that personal links with the officials are very important for getting the work done. This is also supported by value of chi-square which is highly significant at 1 and 5 percent levels of significance. Hence, it can be concluded that influential people get their things done easily and without consuming much time.

\section{Unnecessarily Delaying Tactics}

The response regarding the statement that promotional agencies which have been setup to assist entrepreneurs consume a lot of time show mean score of 2.15 with positive skewness of 0.949 and standard deviation of 1.454. Seven out of ten respondents (69.5 percent) either agree or strongly agree with the statement. Statistical analysis depicts that industrial promotional agencies unnecessarily consume a lot of time and resort delaying tactics. 


\section{No Work Culture}

Responses of the respondents regarding the lack of work culture among the industrial promotional agencies reveals that three-fifth (60.3 percent) of the respondents either disagree or strongly disagree with the statement. The mean score of aggregate responses is 3.57 with negative value of skewness $(-0.540)$ and standard deviation of 1.457 which indicates that a vast majority of the respondents either disagree or strongly disagree with the statement. The value of chi-square is also highly significant. Hence, it can be summed up that poor work culture of promotional agencies is not the reason for withdrawing industries from Himachal.

\section{Seriousness of the Officials}

The opinions of the respondents regarding involvement of Government officers to promote industries show a mean score of 2.82 with skewness of 0.250 of and standard deviation of 1.47. This indicates that the opinion of the respondents is concentrated towards the higher side of mean. Hence, a significant number of respondents either agree or disagree with the statement but are found slightly skewed towards disagreement responses.

\section{Role of Industrial Promotional Agencies in Industrial Development: Factor Analysis}

As indicated by Table 2, Kaiser-Meyer-Olkin Measure of Sampling Adequacy of the present study is significant. The part of study significantly satisfies both the tests.

\section{Table 2: KMO and Bartlett's Test for Role of Industrial Promotional Agencies}

\begin{tabular}{|lc|c|}
\hline Kaiser- Meyer - Olkin Measure of Sampling Adequacy. & .692 \\
& & \\
Bartlett's Test of Sphericity & Approx. Chi-Square & 946.975 \\
& df & 190 \\
& Sig. & .000 \\
\hline
\end{tabular}

Table 3: Total variance explained for Role of Industrial Promotional Agencies

\begin{tabular}{|c|c|c|c|c|c|c|c|c|c|}
\hline \multirow[b]{2}{*}{ Component } & \multicolumn{3}{|c|}{ Initial Eigenvalues } & \multicolumn{3}{|c|}{$\begin{array}{l}\text { Extraction Sums of Squared } \\
\text { Loadings }\end{array}$} & \multicolumn{3}{|c|}{$\begin{array}{l}\text { Rotation Sums of Squared } \\
\text { Loadings }\end{array}$} \\
\hline & Total & $\begin{array}{l}\% \text { of } \\
\text { Variance }\end{array}$ & $\begin{array}{l}\text { Cumulative } \\
\%\end{array}$ & Total & $\begin{array}{l}\% \text { of } \\
\text { Variance }\end{array}$ & $\begin{array}{l}\text { Cumulative } \\
\%\end{array}$ & Total & $\begin{array}{l}\% \text { of } \\
\text { Variance }\end{array}$ & $\begin{array}{l}\text { Cumulative } \\
\%\end{array}$ \\
\hline 1 & 3.608 & 18.039 & 18.039 & 3.608 & 18.039 & 18.039 & 3.103 & 15.513 & 15.513 \\
\hline 2 & 3.332 & 16.659 & 34.698 & 3.332 & 16.659 & 34.698 & 2.242 & 11.212 & 26.725 \\
\hline 3 & 2.083 & 10.416 & 45.114 & 2.083 & 10.416 & 45.114 & 2.051 & 10.257 & 36.982 \\
\hline 4 & 1.626 & 8.132 & 53.246 & 1.626 & 8.132 & 53.246 & 1.946 & 9.731 & 46.713 \\
\hline 5 & 1.355 & 6.775 & 60.021 & 1.355 & 6.775 & 60.021 & 1.796 & 8.982 & 55.695 \\
\hline 6 & 1.151 & 5.755 & 65.777 & 1.151 & 5.755 & 65.777 & 1.640 & 8.202 & 63.897 \\
\hline 7 & 1.018 & 5.089 & 70.866 & 1.018 & 5.089 & 70.866 & 1.394 & 6.969 & 70.866 \\
\hline 8 & .984 & 4.920 & 75.786 & & & & & & \\
\hline 9 & .732 & 3.658 & 79.444 & & & & & & \\
\hline 10 & 623 & 3.113 & 82.557 & & & & & & \\
\hline 11 & .549 & 2.746 & 85.303 & & & & & & \\
\hline 12 & 497 & 2.487 & 87.789 & & & & & & \\
\hline 13 & .431 & 2.153 & 89.943 & & & & & & \\
\hline 14 & 403 & 2.014 & 91.956 & & & & & & \\
\hline 15 & .351 & 1.757 & 93.714 & & & & & & \\
\hline 16 & .330 & 1.652 & 95.366 & & & & & & \\
\hline 17 & 286 & 1.428 & 96.795 & & & & & & \\
\hline 18 & 234 & 1.169 & 97.964 & & & & & & \\
\hline 19 & .218 & 1.092 & 99.056 & & & & & & \\
\hline 20 & .189 & .944 & 100.000 & & & & & & \\
\hline
\end{tabular}

Extraction Method: Principal Component Analysis.

Since it was difficult to visualize out twenty variables, Principal Component Analysis was used for the data reduction. The Kaiser rule is used to drop components which say that drop all values with eigenvalues under 1.0. For this data, seven out of twenty components have Eigen values greater than one and these will play the key role in the analysis. Together they account for 70.86 per cent of variance of the original variables. The first component explains 18.03 percent (Table 3) variance, second component explains 16.65 percent variance, third component explains 10.41 percent variance, fourth component explains 8.13 percent variance, the fifth, sixth and seventh components explains 6.77 percent, 5.75 percent and 5.08 percent variances respectively. 
The Kaiser criterion stopped at 7 components, but some researchers might use the scree plot criterion to stop at 8.

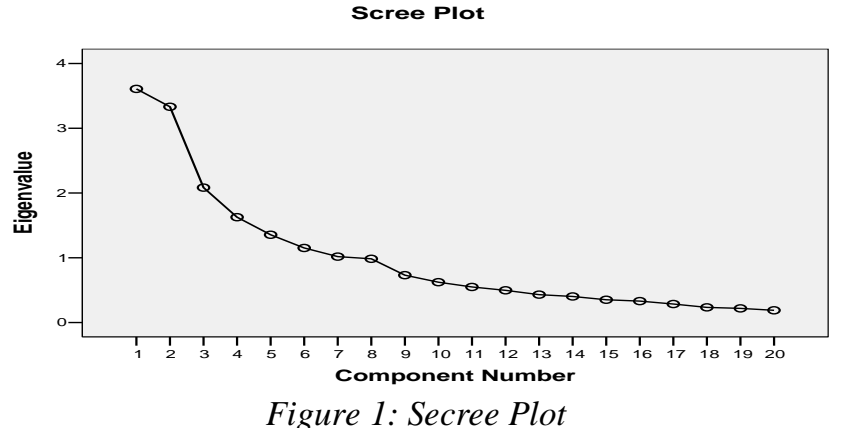

Table 4 contains the rotated factor loadings which are correlations between the variable and the factors. The first factor extracted was the combination of - 'assistance in acquiring land and paper work formalities'. The second factor extracted was the combination of - 'facilitation in setting up the unit, assist in registration and NOC's from other Government Departments'. The third factor signifies the combination of - 'recruiting manpower, providing necessary market information and imparting training for improving technical know-how'. The fourth factor indicates the blend of - 'assistance in marketing product, harassment by government officials, lack of interest shown by officials and poor work culture'. The fifth factor extracted was a combination of - 'seriousness of the officials to promote industrial units and unnecessary delaying tactics'. The sixth factor extracted was a combination of - 'sharing knowledge about various incentives/schemes of Govenment, NOC from state pollution control board, provide valuable information and arrangement of loan'. The seventh factor indicates the combination of - 'personal relations/ connections with high-ups and acquiring working capital'.

Table 4 : Rotated Component Matrix

\begin{tabular}{|l|l|l|l|l|l|l|l|}
\hline \multirow{2}{*}{ Particulars } & \multicolumn{3}{l}{ Component } \\
\cline { 2 - 8 } & 1 & 2 & 3 & 4 & 5 & 6 & 7 \\
\hline Assistance in Acquiring Land & -.864 & .019 & .030 & .016 & -.074 & -.092 & -.086 \\
\hline Paper Work Formalities & -.858 & .003 & .030 & -.090 & -.026 & .129 & -.016 \\
\hline Facilitation in Setting up the Unit & .852 & .020 & -.024 & .052 & .177 & -.023 & -.108 \\
\hline Assist in Registration & .672 & .114 & .286 & -.100 & .161 & .301 & .129 \\
\hline NOC's from Other Government Departments & .538 & -.207 & -.185 & -.178 & .107 & -.259 & .183 \\
\hline Recruiting Staff & .069 & -.813 & .303 & -.119 & -.012 & -.019 & .011 \\
\hline Provide Necessary Market Information & .029 & .803 & -.022 & -.037 & -.120 & -.214 & .206 \\
\hline $\begin{array}{l}\text { Imparted Training for Improving Technical } \\
\text { Know-how }\end{array}$ & .038 & .711 & -.482 & .083 & .137 & -.013 & .048 \\
\hline Assistance for Marketing Product & -.065 & -.251 & .840 & -.033 & .046 & .059 & -.006 \\
\hline Harassment by Government Officials & -.113 & .433 & -.674 & -.069 & .164 & -.102 & -.001 \\
\hline Lack of Interest in Officials & -.114 & -.057 & .593 & -.051 & .211 & -.199 & -.574 \\
\hline Poor Work culture & -.017 & .123 & .143 & -.835 & -.073 & .065 & -.033 \\
\hline $\begin{array}{l}\text { Seriousness of the officials to Promote } \\
\text { Industrial Environment }\end{array}$ & -.063 & .061 & .166 & .755 & -.060 & .004 & .001 \\
\hline Unnecessary Delaying Tactics & .041 & .184 & -.071 & .738 & .069 & .237 & -.016 \\
\hline Provide Knowledge About Various Incentives & .127 & -.090 & -.004 & .005 & .872 & .054 & .084 \\
\hline NOC From State Pollution Control Board & -.259 & -.094 & .016 & -.081 & -.801 & .113 & -.124 \\
\hline Provide Valuable Information & .062 & -.103 & .155 & .065 & .171 & .788 & -.010 \\
\hline Arrangement of Loan & -.081 & -.114 & -.134 & .103 & -.312 & .756 & -.126 \\
\hline Personal Relations/ Connections with High-ups & -.026 & .163 & .019 & -.117 & .266 & .031 & .797 \\
\hline Acquiring Working Capital & .120 & .019 & -.027 & .126 & .045 & -.296 & .524 \\
\hline
\end{tabular}

Extraction Method: Principal Component Analysis.

Rotation Method: Varimax with Kaiser Normalization.

The first factor may be interpreted as 'assist in decree e.g. acquiring land'.

The second factor may be termed as 'assistance in setting up the unit e.g. registration', the third as 'assistance in putting together factors of production and disposing off goods', the fourth as 'biased attitude of officials', the fifth as 'uncompetitive approach of officials', the sixth as 'Industrial agencies assist in 
arrangement of factors of production and provide knowledge about incentives' and the seventh as 'biasness of Industrial Promotional Agencies and assistance in arranging working capital'.

Thus, twenty factors regarding role of Industrial Promotional Agencies were classified into seven basic factors by applying the factor analysis technique of multivariate analysis.

\section{Conclusion}

The government has established various organizations to implement its policies of promotion and development of industrial activities. Registration of the unit with the DIC is not difficult and state industries department also assists the industrialists for acquiring land. Industrial promotional agencies have failed to disseminate proper information to the industrialists. As a result industrialists will have to depend upon consultants. As regards the procedure of government for issue of no objection certificates from state pollution control board and other government departments is concerned, high level of dissatisfaction among the entrepreneurs has been observed. Role of industrial promotional agencies is almost negligible as far as arrangement of finance is concerned and these agencies are not playing any role in arrangement of factors of production of industrial units and marketing of their products. Government officials of these agencies are found harassing people to some extent, though work culture can not be the reason for withdrawing their industrial units from Himachal. Hence, the role of industrial promotional agencies in assisting the industries has been found below expectations.

\section{References}

[1] Gurdeep \& Bhatia, B.S., Industrialisation in backward Areas- Challenge and Opportunities, Indian Journal of Commerce, Dec 1991, pp. 1-7.

[2] Patil, S.Y. "A qualitative Approach Towards Industrialisation for $21^{\text {st }}$ Century", Indian Industry's in 90's Common-Wealth Publishers, New Delhi, 1991, p. 167.

[3] S.S., "Lopsided Industrial Development within an Industrially Induced Division" (Policy Implications for Nineties), Indian Industry'sin90'sCommon-Wealth Publishers, New Delhi, 1991, p. 240.

[4] Kumar, S. Hari, "Industrial Backwardness of Kerala and the Eight Five Year Plan", Indian Industry's in 90's Common-Wealth Publishers, New Delhi, 1991, p.256

[5] Dastane, S.R., "Industrialisation: Trends and Prospects", Indian Industry's in 90's Common-Wealth Publisher, New Delhi, 1991, p.157.

[6] Pathak, Pramod, "Reorienting Rural Industrialisation, Yojana, Oct. 31, 1993, pp 6-8.

[7] Singh, B.P.N., "Industrial Scenario in India; A Victim of Structural Retrogression", Economic Affairs, Vol. 37, Dec 1994, pp 2324.

[8] Gurumoorthy, T.R., "District rural industries project: A boon for rural entrepreneurship" Kurukshetra (A Journal of Ministry of Rural Areas and Employment) Sept., 1995, p. 24.

[9] Joshi, Navin Chandra, "Rejuvenating rural life through industrial growth", Kurushetra (A Journal of Ministry of Rural Areas and Employment)Sept. 1995, p.13.

[10] Bhushan, "Promoting Rural Industrialisation for Higher Productivity and Employment Generation", A Journal of Ministry of Rural Area and Employment, Sep. 1995, pp 48.

[11] Chandra Poojary M., Small-Scale Sector: Myth and Reality," EPW, May, $25^{\text {th }} 1996$

[12] Prasad, Mahesh, "Industrial Development", Yojana, volume 41, No.1, January 1997, pp 56-57.

[13] Ray, Sunil, "Human Face of Industrialisation: A Case Study of Wool-Based Industries in Rajasthan," Economic and Political Weekly, February 22, 1997, pp. M 25-M. 30.

[14] Neogi, Chiranjib and Gosh, Buddhadev, Impact of liberalization on Performance of Indian Industry, Economic and Political Weekly, Feb. 28,2998, pp M16-M24.

[15] Mishra Pulak and Ramakanta Prusty, Indian Industry in a Liberalised Policy Regime, Yojana, Vol. 45, November 2001, pp. 9-28.

[16] T.A. Bhavani "Small Scale Units in the Era of Globalization: Problems and Prospects", Economic and Political Weekly, July $20,2002$.

[17] Singh, SP, Employment, Productivity and Efficiency Trends in Indian Industries, Indian Journal of Economics, Vol LXXXIII, No.330, January 2003, pp. 391-413

[18] Kala Sridhar, Seetharam, Firm Location Decision and Impact on Local Economies, Economic and Political Weekly, Vol. XXXVIII, 39, 2003, pp.4121-4130

[19] Douhan, Robin, Softbrains on the Top of The Queen of Hills, A field study for the attempt to promote IT-industry in Himachal Pradesh, The Indian Journal Of Economics

[20] A report by KPMG for IBEF, India Brand Equity Foundation, c/o Confederation of Indian Industry, Indian States Economy and Business: Himachal Pradesh, August 2005, www.ibef.org

[21] Agrawal M. Ashok and sharma Ojha Rashmi ,Sales Tax Incentive and Industrial Growth, The Indian Journal Of Economics, Vol LXXXV, April2005,No.339.

[22] Sahu Partha Pratim, Adoption of Improved Technology in India's Small-scale Industries: Evidences from a Field Survey, Institute for Studies in Industrial Development, ISID Working Papers 2006/03, April 2006

[23] Taneja Savita, Pant J. C. and Taneja N. K., Industrial Policy and Performance : A Total Factor Productivity Analysis of the Indian Manufacturing Sector, , The Indian Journal Of Economics, Vol LXXXVII, January 2007,No.346.

[24] Aggarwal, Aradhna, ICRIER Working Paper No. 194, Impact of Special EconomicZones on Employment, Poverty and Human Development, May 2007.

[25] Rana Singh Kulwant, Singh Rakesh, Premi Chaman, Singh Shivani, Industrialisation in Himalayan Region with special reference to Himachal Pradesh, Institute of Himalayan Studies, Kanishka Publishers New Delhi, pp 326-335.

[26] Mittal Surabhi , Tripathi Gaurav ,Sethi Deepti ,Development Strategy for the Hill Districts of Uttarakhand, Indian Council of Research on International Economic, Working Paper No. 217, July 2008

[27] Das Kusum Deb, Wadhwa Deepika, Kalita Gunajit, The Employment Potential of Labor

[28] Intensive Industries in India's Organized Manufacturing, Indian Council of Research on International Economic, Working Paper No. 236, June 2009. 